American Journal of Applied Sciences 7 (2): 178-184, 2010

ISSN 1546-9239

(C) 2010 Science Publications

\title{
An in vitro Assessment on the Efficacy of Clay-Based Formulated Cells of Pseudomonas Isolate UTAR EPA2 for Petrol Degradation
}

\author{
A.S.Y. Ting, M.T. Fang and C.S. Tee \\ Department of Science, Faculty of Engineering and Science, \\ University Tunku Abdul Rahman, Kuala Lumpur, Malaysia
}

\begin{abstract}
Problem statement: Application of free-cell forms is usually impractical to achieve satisfactory bioremediative effect because the microbes are encumbered by the biotic and abiotic stresses from the environment. Approach: In this study, a hydrocarbon-degrading bacterium (Pseudomonas isolate UTAR EPA2) was formulated with various combinations of formulative materials, comprising of clay-based carrier materials such as Bentonite (B) and Kaolin (K), enrichment materials such as Non-fat skimmed milk (N) and Sucrose (S) and a UV-protectant agent Paraaminobenzoic acid (P). Formulated cells were treated to sunlight exposure for $6 \mathrm{~h}$ to mimic the conditions in the environment prior to testing for their efficacy in degrading petrol, a mixed hydrocarbon substrate. Results: Cells in all formulations including free-cell suspension were able to degrade petrol with a relatively high degradation efficacy of more than $66 \%$ even after exposure to sunlight. Degradation efficacy was slightly higher for kaolin-based formulated cells compared to bentonite-based formulations, especially after exposure to sunlight, although their percentages of degradation were not statistically different. Nevertheless, kaolin-based formulations have very low viable cell count especially in formulations with P (KP, KNP, KSP, KNSP). This suggested that aside from viable cells, the physical properties of the clays could have also contributed to the degradation of petrol. Conclusion: For storage purposes and applications in the field, we suggest that the bacterium is formulated with bentonite-based formulations especially using Bentonite (B) clay singly, as relatively high percentage of petrol degradation and viable cell count was achieved with this formulation.
\end{abstract}

Key words: Cell viability, formulation, hydrocarbon-degrading bacterium, petrol degradation, UV irradiation

\section{INTRODUCTION}

Formulation of microbial cells has long been established for applications in the agricultural (Meyer, 2003), pharmaceutical (Tanaka et al., 1993; Frokjaer and Hovgaard, 2000) and industrial (Tanaka et al., 1993) sectors. The aims of formulating viable cells are to ensure that adequate cell viability is sustained to increase the efficacy of the cells and to facilitate the delivery and handling processes (Filho et al., 2001). This can be achieved by producing granular formulations, powder or dust formulations, microcapsules, or oilemulsion formulations (Brar et al., 2006). Formulations generally comprise of the active or core material, the carrier material and may or may not include the incorporation of enrichment materials or additives. The core material is usually the active material that has to be preserved or maintained in viable condition for it to produce effect. The core material is mixed with carrier materials such as water, clay or oil to make the formulation safer to handle, easier to apply and better suited for storage. In some formulations, enrichment materials comprising of nutrient-rich medium such as Nonfat Skim Milk (NFSM), skim milk, molasses, trehalose, maltose and sucrose, or additives such ParaAminobenzoic Acid (PABA) and cellulose, are incorporated to further enhance the viability of core materials (Brar et al., 2006; Tu and Randall, 2005).

For bioremediation purposes, formulated microbial cells is most often applied using wet (liquid) formulations by spraying inoculum suspensions on targeted sites, or using dry (solid) formulations where granules or dust are sprayed instead (Brar et al., 2006). The selection on the type of formulation developed and used is dependent on the nature of the active cells and factors related to the site of application such as

Corresponding Author: A.S.Y. Ting, Department of Science, Faculty of Engineering and Science,

University Tunku Abdul Rahman, Jalan Genting Kelang, Setapak 53300, Kuala Lumpur, Malaysia Tel: 603-41079802 Fax: 603-41079803 
application to aquatic or terrestrial landscapes, temperature, climate and water chemistry ( $\mathrm{Tu}$ and Randall, 2005; Sabaratnam and Traquair, 2001). Most often, dry formulations are generally preferred over wet formulations because they provide extended shelf life and are easier to store and transport (Lumsden et al., 1995).

In our study, we tested various combinations of clays with and without the incorporation of enrichment and additive materials to develop a formulation which has potential for large-scale applications. The hydrocarbon-degrading bacterium is most likely applied in the field for future use, hence the testing of the formulative materials in protecting the viable cells after exposure to sunlight (natural UV irradiation) and subsequently their impact on the efficacy of the cells in degrading petrol. This study reports our results on investigations on the different formulation combinations in maintaining the efficacy and viability of the hydrocarbon-degrading bacterium prior to and after exposure to $6 \mathrm{~h}$ sunlight.

\section{MATERIALS AND METHODS}

Isolate preparation: The isolate Pseudomonas (UTAR EPA2) was cultured on Luria-Bertani (LB) agar (Pronadisa) and incubated at room temperature $\left(27 \pm 2^{\circ} \mathrm{C}\right)$ for 2 days prior to use. This isolate was identified as a Pseudomonas isolate based on their sequence alignment to Pseudomonas aeruginosa when sequenced with specific primers Paer16SH (5'-AGG GCA GTA AGT TAA TAC CTT GCT G -3'.) and Paer16SIR (CCA CCT CTA CCG TAC TCT AGC TCA G). This isolate has shown potential in degrading petrol and several other hydrocarbon-based substrates. In this study, 2-day old cultures were established on LB agar (Pronadisa) for usage in the formulation exercise.

Formulation of Pseudomonas isolate: The amount of clay, NFSM, sucrose, PABA and inoculum suspension used in the formulation exercise was pre-determined after several optimization exercises to ensure that the resulting formulation achieved is in granular form. For each clay type, seven combinations of formulations were prepared. Each bentonite-based formulation comprised of $180 \mathrm{~g}$ bentonite clay mixed with $180 \mathrm{~mL}$ of inoculum suspension $\left(15 \log _{10}\right.$ c.f.u. $\mathrm{mL}^{-1}$, absorbance value of 0.200 at $600 \mathrm{~nm}$ ). For formulations requiring a combination of enrichment materials such as NFSM (BN) and Sucrose (BS), $15 \mathrm{~g}$ of NFSM and sucrose was incorporated, respectively. PABA was also added into prepared formulations of Bentonite (BP), bentonite with NFSM (BNP) and Bentonite with
Sucrose (BSP) at a rate of $1.5 \mathrm{~g}$ for every $180 \mathrm{~g}$ of bentonite clay. The formulation containing all enrichment and additive materials tested (BNSP) was also prepared using similar compositions. For formulation using just Bentonite clay (B), no other additives were incorporated alongside the inoculum. For kaolin-based formulations, each combination comprised of $240 \mathrm{~g}$ kaolin clay mixed with $240 \mathrm{~mL}$ of inoculum suspension (15 $\log _{10}$ c.f.u. $\mathrm{mL}^{-1}$, absorbance value of 0.200 at $600 \mathrm{~nm})$. Formulations requiring NFSM (KN) and sucrose (KS) were incorporated with $10 \mathrm{~g}$ of NFSM and sucrose, respectively. Formulations with PABA (KP, KNP and KSP) were prepared by adding $1.0 \mathrm{~g}$ of PABA for every $240 \mathrm{~g}$ of kaolin clay. The formulation with all enrichment and additive materials tested (KNSP) was prepared using similar compositions and the formulation comprising of just Kaolin clay $(\mathrm{K})$ was not incorporated with any other additives. Three formulations, Free-Cell suspension (FC), Bentonite Clay (BC) and Kaolin Clay (KC) only without the bacterial cells, designated as controls were also prepared. Free-cell formulation was prepared as $180 \mathrm{~mL}$ broth suspension $\left(15 \log _{10}\right.$ c.f.u. $\mathrm{mL}^{-1}$, absorbance value of 0.200 at $600 \mathrm{~nm}$ ). BC was prepared by mixing $180 \mathrm{~g}$ bentonite clay with $180 \mathrm{~mL}$ of sterile distilled water and $\mathrm{KC}$ was prepared similarly with $240 \mathrm{~g}$ of kaolin clay and $240 \mathrm{~mL}$ of sterile distilled water. The bentonite and clay-based granular formulations were then dried in an oven (Memmert) at $30 \pm 2^{\circ} \mathrm{C}$ for 3 days, grind and sieved through a $1.0 \mathrm{~mm}$ sieve (Cole-Parmer) and stored in $1000 \mathrm{~mL}$ glass Schott bottles at room temperature $\left(27 \pm 2^{\circ} \mathrm{C}\right)$ for subsequent experiments.

Efficacy assessment: Test tubes containing $1.0 \mathrm{~mL}$ of petrol (Esso) and $20 \mathrm{~mL}$ of sterile deionized water were first prepared. To each tube designated for testing using bentonite-based, kaolin-based formulations and freecell suspension, 1.0 and $2.0 \mathrm{~g}$ and $0.5 \mathrm{~mL}$ of the respective formulations (suspension) were added accordingly. Formulations which required exposure to sunlight (natural UV irradiation) were placed into glass petri dish and exposed to sunlight for $6 \mathrm{~h}$. They were then added into test tubes containing similar compositions of petrol and sterile deionized water. The amount of petrol degraded was quantified to determine the amount of petrol degraded. Petrol was first extracted using acetone (Merck) and then by hexane (Merck). Acetone was first added into each tube, vortexed for $30 \mathrm{sec}$ and added with hexane and vortexed for another $1 \mathrm{~min}$. This was followed by 5 min of centrifugation (Sigma $3 \mathrm{~K} 30$ Sartorius) at $9000 \mathrm{rev} \cdot \mathrm{min}^{-1}$ and $4^{\circ} \mathrm{C}$. The top clear layer formed was 
collected for analysis using the Gas ChromatographyMass Spectrometer (GC-MS), while the bottom layer containing clays, bacterial cells and aqueous solution was discarded.

The following were the conditions for the GC-MS analysis operated using the GCMS-QP2010 Plus Gas Chromatograph/Mass Spectrometer from Shimadzu. The GC-MS operates with the AOC 20I Auto Injector and the chromatographic column used was type BPX5 with an internal diameter of $0.25 \mathrm{~mm}$ and length of $30 \mathrm{~m}$. The carrier gas used was helium (flow of $1.38 \mathrm{~mL} \mathrm{~min}{ }^{-1}$ ) and the temperature analysis program preset at $60^{\circ} \mathrm{C}$ for 5 min with a final temperature of $220^{\circ} \mathrm{C}$ at the rate of $6^{\circ} \mathrm{C} \mathrm{min}^{-1}$. The temperature of induction port was determined at $240^{\circ} \mathrm{C}$ while the temperature of the FID was pre-set at $315^{\circ} \mathrm{C}$ with a split ratio of 1:20. The volume of petrol residue detected in the sample was determined based on a standard curve constructed using similar extraction and analysis conditions. The following equation was employed to calculate the percentage of petrol degradation:

$$
[(\mathrm{Vo}-\mathrm{Vr}) / \mathrm{Vo}] \times 100 \%
$$

Where:

$\mathrm{Vo}=$ The original volume of petrol added to the sample $\mathrm{Vr}=$ The petrol residue detected in the sample after treatment

The procedure was also repeated for all bioformulations exposed to $6 \mathrm{~h}$ of sunlight to determine the efficacy of formulated cells in petrol degradation after sunlight exposure. Efficacy assessment was conducted after two months of storage on a monthly interval for the next 4 months.

Viability assessment: The viability of formulated Pseudomonas cells was assessed and compared to freecell suspension (control, FC) to determine the effect of formulants on cell viability. Viability assessment was performed every month for 6 months. During each assessment, $1.0 \mathrm{~g}$ of bentonite-based formulation was mixed in $15 \mathrm{~mL}$ of sterile distilled water and a serial dilution performed until $10^{4}$ dilution times. From each dilution factor, $0.05 \mathrm{~mL}$ aliquot was plated onto $\mathrm{LB}$ agar plates. The plates were then incubated at room temperature $\left(27 \pm 2^{\circ} \mathrm{C}\right)$ for 2 days and the colonies formed enumerated. The procedure was repeated using $2.0 \mathrm{~g}$ of kaolin-based formulations and $0.50 \mathrm{~mL}$ of freecell suspension.

Experimental design and statistical analysis: The experiments were conducted in a complete randomized design, with duplicates for each viability and efficacy assessments. Results obtained were analyzed with the SAS Program (Statistical Analysis System). The mean comparison for formulations exposed and non-exposed to sunlight was compared with Tukey's Studentized Range Test $\left(\mathrm{HSD}_{0.05}\right)$. The comparison of the effect of sunlight exposure within a single bioformulation was compared with T-test ( $\mathrm{p} \geq 0.05)$.

\section{RESULTS AND DISCUSSION}

Efficacy of formulated Pseudomonas cells in degrading petrol: Generally, the degradation efficacy of Pseudomonas cells were relatively higher for cells in Free-Cell suspension (FC) compared to kaolin and bentonite-based formulations, with mean percentages of degradation of $96.01,87.18$ and $82.44 \%$, respectively. In Free-Cell suspension (FC), Pseudomonas cells have direct contact with petrol, hence a more efficient degradation activity. After exposure to sunlight, the degradation activity increased to $96.90 \%$ from $95.11 \%$ (without sunlight exposure) (Fig. 1).

Comparisons between the two clay-based carrier materials, irrespective of the UV irradiation factor, indicated that most kaolin-based formulations have higher mean of petrol degradation. Formulations with Kaolin singly (K), with Sucrose (KS) and NFSM (KN), were able to produce good degradation efficacy with a mean of $92.19,90.70$ and $87.10 \%$, respectively. This could be attributed to the physical and mineral compositions of the kaolin clay, which on its own, has been shown to act as a catalyst in oil and gas refining breaking heavier hydrocarbon molecules into lighter products (Pereira et al., 2000; Rong and Xiao, 2002; Adamis et al., 2005).

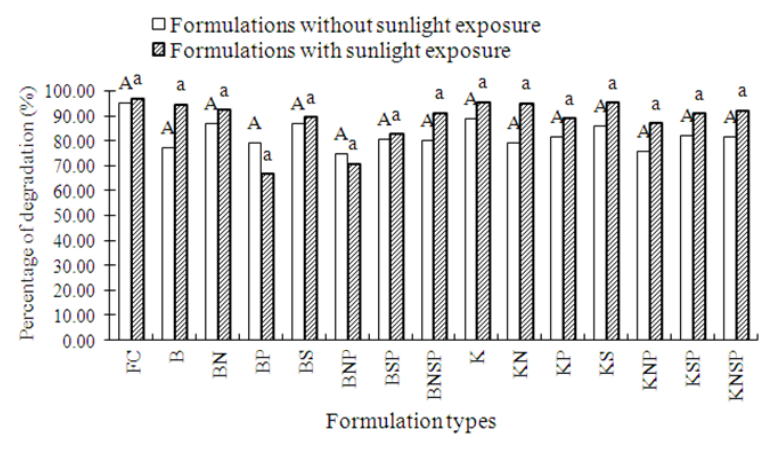

Fig. 1: Percentage of petrol degradation by Pseudomonas cells in various formulations with and without exposure to $6 \mathrm{~h}$ of sunlight. Means with the same letters and captions are not Significantly Different $\left(\mathrm{HSD}_{(0.05)}\right)$ 
Am. J. Applied Sci., 7 (2): 178-184, 2010

Table 1: Results of T-test comparison on the degradation efficacy of formulations exposed and non-exposed to sunlight within a single formulation

\begin{tabular}{lcl}
\hline T-test & t-value & $\operatorname{Pr}>|t|$ \\
\hline FC & -0.74 & 0.51 \\
B & -1.19 & 0.32 \\
BN & -1.44 & 0.24 \\
BP & 0.64 & 0.57 \\
BS & -0.69 & 0.54 \\
BNP & 0.22 & 0.84 \\
BSP & -0.17 & 0.88 \\
BNSP & -2.60 & 0.08 \\
K & -0.92 & 0.43 \\
KN & -1.09 & 0.36 \\
KP & -1.37 & 0.26 \\
KS & -0.99 & 0.39 \\
KNP & -1.43 & 0.25 \\
KSP & -1.09 & 0.36 \\
KNSP & -1.26 & 0.30 \\
\hline
\end{tabular}

Note: FC: Free-Cell suspension; B: Bentonite clay; N: Non-fat skim milk; S: Sucrose; P: PABA. *: Statistically different $(\mathrm{p} \leq 0.05)$

The benefits of kaolin-based formulations in ensuring high petrol degradation were most evident when formulations were exposed to sunlight. In addition to the catalytic and shielding properties, kaolin also has good cation exchange capacity which enhances the bacterial metabolic activity (Adamis et al., 2005). After sunlight exposure, the kaolin-based formulations collectively produced a mean degradation efficacy of $92.14 \%$, followed by bentonite-based formulations with $84.30 \%$. Both clay-based formulations however, have lower degradation efficacy compared to free-cell suspension irrespective of the UV irradiation factor.

The addition of sucrose, NFSM and PABA in various combinations to kaolin and bentonite-based formulations did not significantly enhance nor inhibit the degradation activity by the Pseudomonas cells. They were also not particularly useful in rendering benefits as UV protectants as the degradation efficacy compared between sunlight and non-sunlight exposed formulations within the same formulation, were not significantly different (Table 1). Although there is a slight inclination towards better performances by kaolin-based formulations incorporated with sucrose and NFSM (KS, KN), these effects were not consistent with bentonite-based formulations (BS, BN). This suggested that the clay-based carrier materials may have a more significant impact on petrol degradation rather than the enrichment and additive materials incorporated.

Viability of Pseudomonas cells in various formulations: The type of formulants used influenced the viability of Pseudomonas cells especially upon sunlight exposure. The presence of clay-based carriers especially bentonite clay may have conferred protection

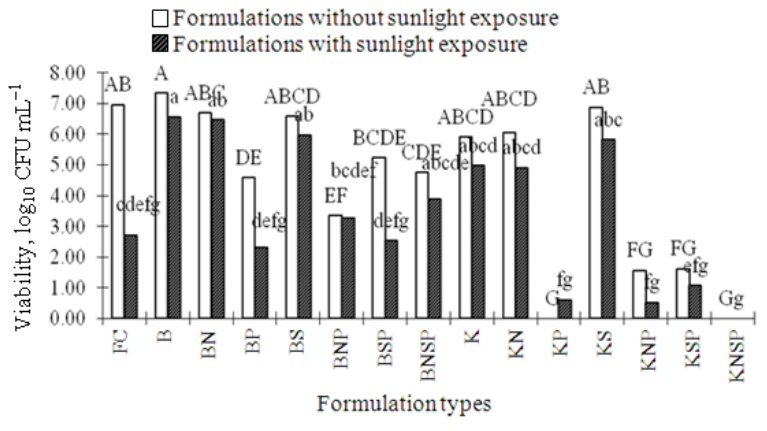

Fig. 2: Mean viable cell count of Pseudomonas cells in various formulations with and without exposure to $6 \mathrm{~h}$ of sunlight. Means with the same letters and same captions are not Significantly Different $\left(\operatorname{HSD}_{(0.05)}\right)$

to the cells as upon sunlight exposure, the mean viable cell count for bentonite-based formulations were generally higher than and kaolin-based formulation and free-cell suspension, with 4.44, 2.57 and $2.70 \log _{10}$ c.f.u. $\mathrm{mL}^{-1}$, respectively (Fig. 2). This showed that clay materials benefited the cells by providing large surface areas which act as an effective survival unit for nutrient absorption and protection when exposed to sunlight (Lunsdorf et al., 2000).

All bentonite-based formulations with and without exposure to sunlight, were able to maintain the highest viable cell count throughout the storage period, with a mean cell count of $4.98 \log _{10}$ c.f.u. $\mathrm{mL}^{-1}$, compared to free-cell suspension and kaolin-based formulations, with 4.84 and $2.86 \log _{10}$ c.f.u. $\mathrm{mL}^{-1}$, respectively (Fig. 2). Irrespective of the UV irradiation factor, the mean viable cell count for bentonite-based formulations, especially $\mathrm{B}, \mathrm{BN}$ and $\mathrm{BS}$, were at levels higher than $6 \log _{10}$ c.f.u. $\mathrm{mL}^{-1}$ (Fig. 2). Among the bentonite formulations, formulation with Bentonite singly (B) proved to be the most useful as highest number of viable cells were recovered, even when compared to free-cell suspension in conditions not exposed to sunlight (Fig. 2). Cell viability was also not significantly affected (Table 2) when the formulation was exposed to sunlight, with less than $1 \log _{10}$ c.f.u. $\mathrm{mL}^{-1}$ reduction from 7.35-6.58 $\log _{10}$ c.f.u. $\mathrm{mL}^{-1}$ (Fig. 2). This is attributed to the high cation exchange capacity and great adsorption ability by bentonite clay (Adamis et al., 2005). High cation exchange capacity enhances bacterial metabolic activity leading to higher viability (Beveridge, 1988), while high adsorption ability enables the molecular binding of inorganic cations, organic cations and bio-organic particles, not only to the surface but also between the layers of clay. This makes bentonite clay an ideal carrier material that provides protection for the cells against toxic and adverse environmental conditions (Gentry et al., 2004). 
Am. J. Applied Sci., 7 (2): 178-184, 2010

Table 2: Results of T-test comparison on the viability of formulations exposed and non-exposed to sunlight within a single formulatio

\begin{tabular}{lll}
\hline T-test & t-value & $\operatorname{Pr}>|t|$ \\
\hline FC & 3.83 & 0.01 \\
B & 0.37 & 0.08 \\
BN & 0.68 & 0.52 \\
BP & 2.48 & 0.05 \\
BS & 1.99 & 0.09 \\
BNP & 0.80 & 0.45 \\
BSP & 2.39 & 0.05 \\
BNSP & 1.10 & 0.31 \\
K & 2.85 & 0.03 \\
KN & 3.26 & 0.02 \\
KP & -1.00 & 0.36 \\
KS & 3.66 & 0.01 \\
KNP & 0.97 & 0.37 \\
KSP & 0.55 & 0.60 \\
KNSP & 0.00 & 0.00 \\
\hline
\end{tabular}

Note: FC: Free-Cell suspension; B: Bentonite clay; N: Non-fat skim milk; S: Sucrose; P: PABA. *: Statistically different $(\mathrm{p} \leq 0.05)$

Interestingly, our results showed that kaolin-based formulations were less suitable in maintaining cell viability, especially after exposure to sunlight. Three of the seven kaolin-based formulations, $\mathrm{K}, \mathrm{KN}$ and $\mathrm{KS}$, recorded significant reductions in the number of cells recovered from formulations exposed to sunlight (Table 2). Kaolin clay has lower adsorption efficacy which is limited to the surface of the particles (Adamis et al., 2005). As such, the cells, enrichment and additive materials added to kaolin-based formulations may not be held strongly between the layers of kaolin, resulting in poor viability especially after exposure to sunlight. Formulations such as KP and KNSP, were the least suitable as inconsistent numbers of viable cells were recovered throughout the experimental period. KNSP in fact, did not produce any viable cells. The most suitable kaolin-based formulation was KS with relatively higher number of viable cells before and after sunlight exposure (Fig. 2), although there was a significant reduction in the number of cells after sunlight exposure (Table 2).

Evaluation on the impact of sucrose, NFSM and PABA showed that PABA has inclination in rendering inhibitory effects towards Pseudomonas cells, while sucrose and NFSM were beneficial. Addition of PABA to Bentonite (BP) and Kaolin (KP) showed reduced levels of viable cell recovery (Fig. 2). PABA occurs naturally as an intermediate in the bacterial synthesis of folic acid and frequently served as UV protectant especially in biopesticides (Hadapad et al., 2009). However, when incorporated into formulations, PABA showed antimicrobial properties and caused greater inhibitory effects compared to other organic acids (Richards et al., 1994). In our study, PABA did not indicate exceptional beneficial role as a UV protectant as viable cells recovered from formulations with PABA were not significantly higher after sunlight exposure (Fig. 2 and Table 2). The detrimental effect of PABA was less severe in bentonite formulations coincorporated with sucrose and NFSM, as seen in BNP, BSP and BNSP (Fig. 2). Contrary, viable cell count remained poor for kaolin-based formulations (KNP, KSP, KNSP) (Fig. 2). The benefits of sucrose and NFSM was also evident in the following formulations; BN, BS, KN and KS. Sucrose and NFSM are common enrichment materials providing necessary nutrients especially carbon source to support cell growth (Lee and Chang, 2004). They also function as rehydration medium and osmoprotectant agent in preventing severe desiccation of cells upon sunlight exposure (Costa et al., 2000; Gouffi and Blanco, 2000).

Influence of viability of Pseudomonas cells on petrol degradation: Higher cell viability may not necessary indicate that good degradation activity may occur. In our study, we observed that kaolin-based formulations, which have significantly lower viable cell count $\left(2.57 \log _{10}\right.$ c.f.u. $\left.\mathrm{mL}^{-1}\right)$ compared to bentonitebased formulations ( $4.98 \log _{10}$ c.f.u. $\mathrm{mL}^{-1}$ ), have shown relatively higher degradation activity, especially after sunlight exposure with $92.14 \%$ compared to $83.98 \%$, respectively. Even free-cell suspension, with only $2.70 \log _{10}$ c.f.u. $\mathrm{mL}^{-1}$ after sunlight exposure, was able to achieve $96.90 \%$ degradation activity. Results from formulations without sunlight exposure produced a similar trend, where kaolin-based formulations with only $\quad 3.15 \quad \log _{10} \quad$ c.f.u. $\mathrm{mL}^{-1}$ recorded $82.22 \%$ degradation activity compared to bentonite-based formulations with $80.90 \%$ degradation activity from $5.51 \log _{10}$ c.f.u. $\mathrm{mL}^{-1}$. In both cases, Free-Cell suspension (FC) has good degradation activity with 95.11 and $96.90 \%$, although the number of viable cells was significantly reduced. In view of this, we presume the physico-chemical properties of the formulants and the surface contact area influenced the degradation activity as well other than the number of viable cells, especially surface contact with petrol. Our results for degradation activity revealed that as clay material, kaolin with $96.57 \%$ degradation activity may have better affinity in binding petrol especially under sunlight exposure compared to bentonite (80.93\%). Similarly, without sunlight exposure, kaolin has better binding capacity than bentonite with $88.48 \%$ degradation compared to $67.80 \%$. The binding and adsorption of clay-based materials with petrol and their role in petrol bioremediation is not well-known. As such, we can only proposed further studies to establish this. 


\section{CONCLUSION}

To conclude, our study has shown that formulated cells can degrade petrol effectively in conditions with and without exposure to $6 \mathrm{~h}$ sunlight. For cells aimed for environmental application, they are highly recommended for formulation as they can be protected from the sunlight exposure compared to free-cell suspensions. Generally, clay-based formulation showed beneficial effects in protecting the cells from the deleterious impacts of sunlight (UV radiation). We also discovered that enrichment materials were effective in enhancing cell viability especially sucrose and NFSM, but were not exceptionally beneficial in the degradation process. PABA was determined as an unsuitable additive material despite its UV protectant claims andis recommended for omission from future formulation studies. Formulated cells with solely bentonite clay was proposed as the most beneficial formulation with potential for large-scale testing as good viability and efficacy results were obtained, even after exposure to sunlight. We also suggest more studies be done to look into the physico-chemicals aspects of the formulations and their influence on petrol degradation.

\section{ACKNOWLEDGEMENT}

The researchers thank the Malaysian Ministry of Science, Technology and Innovation for the financial assistance provided under the Science Fund scheme (Project No.: 02-02-11-SF0037).

\section{REFERENCES}

Adamis, Z., R.B. Williams and J. Fodor, 2005. Bentonite, Kaolin and Selected Clay Minerals. International Programme on Chemical Safety (IPCS)-World Health Organization (WHO), Geneva, pp: 24-38. http://whqlibdoc.who.int/ehc/WHO_EHC_231.pdf

Beveridge, T.J., 1988. The bacterial surface: General considerations towards design and function. Can. J. Microbiol., 34: 363-372. DOI: 10.1139/m88-067

Brar, S.K., M. Verma, R.D. Tyagi and J.R. Valero, 2006. Recent advances in downstream processing and formulations of Bacillus thuringiensis based biopesticides. Process Biochem., 41: 323-342. DOI: 10.1016/j.procbio.2005.07.015

Costa, E., J. Usall, N. Teixido, N. Garcia and I. Vinas, 2000. Effect of protective agents, rehydration media and initial cell concentration on viability of Pantoea agglomerans strain CPA-2 subjected to freeze-drying. J. Applied Microbiol., 89: 793-800. DOI: $10.1046 /$ j.1365-2672.2000.01182.x
Filho, A.B., A.B. Alves, N.T. August, R.M. Pereira and L.F.A. Alves, 2001. Stability and persistence of two formulations containing Anticarsia gemmatalis Nuclear Polyhedrovirus (AgMNPV). J. Neotrop. Entomol., 30: 411-416. DOI: 10.1590/S1519566X2001000300012

Frokjaer, S. and L. Hovgaard, 2000. Pharmaceutical Formulation Development of Peptides and Proteins. Taylor and Francis Limited, London, ISBN: 0748407456, pp: 238.

Gentry, T., C. Rensing and I.L. Pepper, 2004. New approaches for bioaugmentation as a remediation technology. Crit. Rev. Environ. Sci. Technol., 34: 447-494. DOI: $10.1080 / 10643380490452362$

Gouffi, K. and C. Blanco, 2000. Is the accumulation of osmoprotectant the unique mechanism involved in bacterial osmoprotection? Int. J. Food. Microbiol., 55: 171-174. DOI: 10.1016/S0168-1605(00)00192-6

Hadapad, A.B., R.S. Hirea, N. Vijayalakshmia and T.K. Dongre, 2009. UV protectants for the biopesticide based on bacillus sphaericus neide and their role in protecting the binary toxins from UV radiation. J. Invertebrate Pathol., 100: 147-152. DOI: 10.1016/j.jip.2008.12.003

Lee, S.Y. and H.N. Chang, 2004. High cell density cultivation of Escherichia coli W using sucrose as a carbon source. Biotechnol. Lett., 15: 971-974. DOI: $10.1007 / \mathrm{BF} 00131766$

Lumsden, R.D., J.A. Lewis and D.R. Fravel, 1995. Formulation and Delivery of Biocontrol Agents for Use against Soilborne Plant Pathogens. In: Biorational Pest Control Agents: Formulation and Delivery, Hall, F.R. and J.W. Barry (Eds.). American Chemical Society, Washington, pp: 166-182.

Lunsdorf, H., R.W. Erb, W.R. Abraham and K.N. Timmis, 2000. Clay hutches: A novel interaction between bacteria and clay minerals. J. Environ. Microbiol., 2: $\quad 161-168$. DOI: $10.1046 /$ j.14622920.2000.00086.x

Meyer, S.L.F., 2003. United States department of agriculture-agricultural research service research programs on microbes for management of plantparasitic nematodes. J. Pest Manage. Sci., 59: 665-670. DOI: $10.1002 /$ ps. 708

Pereira, M.O., M.J. Vieira and L.F. Melo, 2000. The effect of clay particles on the efficacy of a biocide. Water Sci. Technol., 14: 61-64. http://repositorium.sdum.uminho.pt/bitstream/1822 /4467/1/Biofilms-NYPereira\%5B2\%5D.pdf

Richards, R.M.E., D.K.L. Xing and T.P. King, 1994. Activity of P-aminobenzoic acid compared with other organic acids against selected bacteria. J. Applied Microbiol., 78: 209-215. DOI: 10.1111/j.1365-2672.1995.tb05018 
Rong, T.J. and J.K. Xiao, 2002. The catalytic cracking activity of the kaolin-group minerals. Mater. Lett., 57: 297-301. DOI: $10.1016 /$ S0167$577 \mathrm{X}(02) 00781-4$

Sabaratnam, S. and J.A. Traquair, 2001. Formulation of a Streptomyces biocontrol agent for the suppression of Rhizoctonia damping-off in tomato transplants. Biol. Control, 23: 245-253. DOI: 10.1006/bcon.2001.1014

Tanaka, A., T. Tosa and T. Kobayashi, 1993. Industrial Application of Immobilized Biocatalysts. Marcel Dekker, Inc., New York, United States of America. pp: 3-67.
Tu, M. and J.M. Randall, 2005. Adjuvants. In: Weed Control Methods Handbook: Tools and Techniques for Use in Natural Areas, Tu, M., C. Hurd and J.M. Randall (Eds.). The Nature Conservancy's Global Invasive Species Team, United States of America, pp: 8.1-8.225. 